\author{
Olga JANUSZKO, JOANNA KAŁUŻA \\ Katedra Żywienia Człowieka \\ Wydział Nauki o Żywieniu Człowieka i Konsumpcji \\ Szkoła Główna Gospodarstwa Wiejskiego w Warszawie \\ Nowoursynowska 159C, 02-776 Warszawa \\ E-mail: olga_januszko@sggw.pl
}

\title{
ZNACZENIE RYB I PRZETWORÓW RYBNYCH W ŻYWIENIU CZŁOWIEKA - ANALIZA KORZYŚCI I ZAGROŻEŃ
}

\section{WPROWADZENIE}

W 2016 r. Instytut Żywności i Żywienia (IŻŻ) opublikował zaktualizowana wersję Piramidy Zdrowego Żywienia i Aktywności Fizycznej dla osób dorosłych (JAROsz 2016). Rok później po raz pierwszy przedstawił w tej formie zalecenia skierowane do osób starszych (JAROSZ 2017b), natomiast w 2019 r. ukazała się Piramida Zdrowego Żywienia i Stylu Życia dla dzieci i młodzieży (JAROsz 2019). Piramida żywienia stanowi graficzny opis odpowiednich proporcji różnych grup produktów spożywczych, które powinny znaleźć się w codziennej diecie; przy czym im wyższe piętro piramidy tym mniejsza częstotliwość i ilość spożycia produktów $z$ danej grupy. Zgodnie z zasadami prawidłowego żywienia promowanymi przez IŻŻ, bez względu na grupę wiekowa, ryby powinny być spożywane minimum dwa razy w tygodniu.

Spożycie ryb i owoców morza jest zalecane ze względu na ich wysoka wartość odżywczą. Jednak zanieczyszczenie środowiska sprawia, że poza niezbędnymi składnikami odżywczymi, moga być one także źródłem substancji szkodliwych. W zwiazku $z$ tym w niniejszym artykule przedstawiono korzyści i zagrożenia wynikające ze spożycia ryb, przetworów rybnych i owoców morza.

\section{WIELKOŚĆ I STRUKTURA SPOŻYCIA}

Polska należy do krajów o niskim spożyciu ryb i owoców morza. Spożycie produktów rybołówstwa w Polsce, na tle innych krajów europejskich, przedstawiono na Ryc. 1. Według danych Organizacji Narodów Zjednoczonych do spraw Wyżywienia i Rolnictwa (ang. Food and Agriculture Organization of the United Nations, FAO) liderami w konsumpcji tej grupy produktów sa Portugalia $(55,9 \mathrm{~kg} /$ osobę) oraz Hiszpania (45,2 kg/osobę). Średnia spożycia w państwach UE-28 wynosi $25,1 \mathrm{~kg}$, natomiast w Polsce jest ona blisko dwukrotnie niższa od średniej unijnej (13,6 $\mathrm{kg} /$ osobe) (FAO 2015).

Według danych Instytutu Ekonomiki Rolnictwa i Gospodarki Żywnościowej (IERiGŻ) od kilku lat spożycie produktów rybołówstwa w kraju kształtuje się na podobnym poziomie, tj. około $12-14 \mathrm{~kg}$ na mieszkańca rocznie.

W 2017 r. spożycie ryb i owoców morza w Polsce wyniosło $12,5 \mathrm{~kg} /$ mieszkańca i było o 5\% mniejsze, niż w roku poprzednim. Zmniejszenie spożycia dotyczyło wyłacznie ryb morskich i dwuśrodowiskowych (spożycie obniżone o 9\%), przy jednoczesnym wzroście konsumpcji owoców morza (o 16\%) i ryb słodkowodnych (o 9,5\%). Wśród ryb morskich w największym stopniu zmniejszył się popyt na łososia, tuńczyka i dorsza, co było spowodowane wzrostem cen surowców importowanych i w konsekwencji cen detalicznych oraz znacznego pogorszenia relacji cen tych ryb do cen miessa zwierzat rzeźnych, a szczególnie drobiu. Wśród ryb słodkowodnych zmniejszyła się konsumpcja karpia i pstraga. Powodem był spadek importu tych gatunków. Zahamowana została tendencja spadkowa spożycia pangi $(0,5 \mathrm{~kg} /$

Słowa kluczowe: dioksyny, metylortęć, owoce morza, ryby, spożycie, wartość odżywcza, wielonienasycone kwasy tłuszczowe, witamina D 


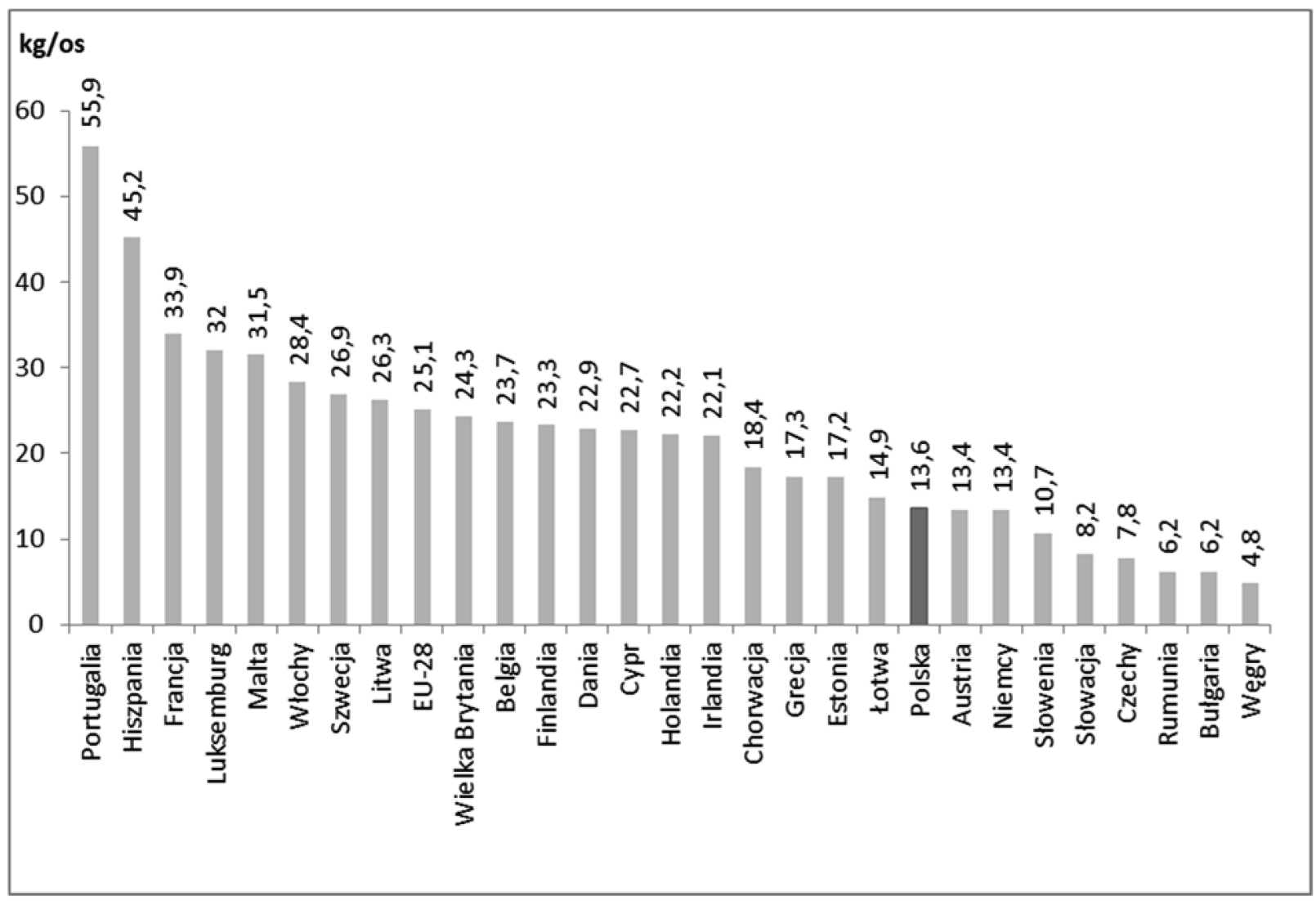

Ryc. 1 Spożycie ryb i owoców morza w państwach członkowskich UE-28 w 2015 r. (kg masy żywej/ mieszkańca/rok) (FAO 2015).

mieszkańca), natomiast skokowo zwiększył się popyt na tilapię $(0,3 \mathrm{~kg} /$ mieszkańca). Należy zaznaczyć, że zarówno panga, jak i tilapia dostępne sa na rynku krajowym wyłącznie w postaci mrożonych filetów $z$ Chin oraz Wietnamu. Spośród owoców morza istotnie zwiększyło się spożycie krewetek (o $15,4 \%)$ wynoszac $0,3 \mathrm{~kg} /$ mieszkańca.

Ze względu na niska dynamikę cen detalicznych ryb i owoców morza przewiduje się wzrost spożycia tych produktów w najbliższym czasie, zakładając jednocześnie podobny do obecnego poziomu import podstawowych gatunków ryb (IERIGż-PIB 2018).

\section{ZALECENIA ŻYWIENIOWE}

Aktualne rekomendacje różnych grup ekspertów dotyczace spożycia ryb i owoców morza przedstawiono w Tabeli 1. Spożywanie ryb co najmniej 2 razy w tygodniu dla zdrowych osób dorosłych zalecane jest przez żywieniowców na całym świecie. Jednak ze względu na występowanie w tych produktach zanieczyszczeń chemicznych, dla grup wrażliwych, to jest kobiet w ciaży, karmiących piersia i dzieci wprowadzono pewne ograniczenia, jednocześnie podkreślając, że korzyści zdrowotne ze spożycia umiarkowanych ilości ryb jako źródła kwasów n-3 przez kobiety w ciaży jednoznacznie przeważaja nad ryzykiem (MoJskA i współaut. 2017).

Instytut Żywności i Żywienia (JAROSZ 2017a) w opracowaniu Normy żywienia dla populacji Polski opublikował wykaz gatunków ryb zalecanych do spożycia przez osoby klasyfikowane do tzw. grup wrażliwych (Tabela 2), dodatkowo rekomendując ograniczenie spożycia ryb pochodzacych $z$ akwenów o wysokim stopniu zanieczyszczenia metalami ciężkimi oraz ryb drapieżnych (MOJSKA i współaut. 2017).

Według Instytutu Matki i Dziecka (WEKER i współaut. 2014) ryby do diety niemowląt należy wprowadzać w 7.-8. miesiącu życia, przy czym powinny one być spożywane przynajmniej raz lub dwa razy w tygodniu. Podawanie ryb w okresie niemowlęcym sprzyja rozwojowi tolerancji immunologicznej i zmniejsza ryzyko wystapienia alergii. Ze względu na możliwość zanieczyszczenia ryb substancjami szkodliwymi, szczególnie rtęcią czy dioksynami, nie zaleca się podawania niemowlętom ryb drapieżnych, takich jak rekin, miecznik, makrela królewska czy płatecznik. 
Tabela 1. Zalecenia dotyczące spożycia ryb i owoców morza na podstawie rekomendacji różnych grup ekspertów.

\begin{tabular}{|c|c|}
\hline Grupa populacyjna & Zalecenia \\
\hline \multicolumn{2}{|c|}{ Food Standards Australia New Zealand (FsANZ 2011) } \\
\hline Dzieci do 6 r.ż. (1porcja $=75 g)$ & 2-3 porcje ryb i owoców morza/tydzień bez wymienienia gatunku lub 1 \\
\hline Kobiety w ciąży/planujące ciażę (1porcja & porcja gardłosza atlanckiego / tydzień \\
\hline$=150 \mathrm{~g})$ & lub 1 porcja rekina, miecznika lub marlina / 2 tygodnie \\
\hline Pozostałe grupy populacyjne $(1$ porcja $=$ & 2-3 porcje ryb i owoców morza/tydzień bez wymienienia gatunku lub \\
\hline 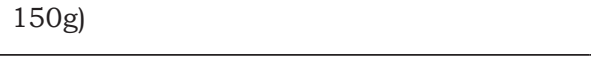 & 1 porcja rekina, miecznika lub marlina / tydzień \\
\hline \multicolumn{2}{|c|}{ Food and Drug Administration (FDA 2017) } \\
\hline Dzieci i młodzież 2-18 lat & $\begin{array}{l}\text { 1-2 porcje ryb i owoców morza/tydzień, gatunki zalecane jako najlep- } \\
\text { szy }^{1} \text { lub dobry wybór }{ }^{2}\end{array}$ \\
\hline \multirow[t]{2}{*}{ Kobiety w ciaży } & $\begin{array}{l}\text { 2-3 porcje ryb i owoców morza/tydzień, gatunki zalecane jako najlep- } \\
\text { szy wybór }{ }^{1}\end{array}$ \\
\hline & lub 1 porcja ryb i owoców morza /tydzień, gatunki dobrego wyboru ${ }^{2}$ \\
\hline \multicolumn{2}{|c|}{ Instytut Żywności i Żywienia (JAROsz 2017a) } \\
\hline Populacja cała & 2 porcje ryb/tydzień, w tym łosoś do $100 \mathrm{~g}$, śledź do $400 \mathrm{~g}$ \\
\hline
\end{tabular}

European Food Safety Authority (EFSA 2010, 2012b, 2014 ) i Food and Agriculture Organization of the United Nations (FAO 2010)

\begin{tabular}{ll}
\hline Dzieci i młodzież 2-18 lat & 2 porcje ryb/tydzień, w tym 1 porcja ryb tustych \\
Kobiety w ciąży/karmiące piersią & 2 porcje ryb/tydzień, w tym 1 porcja ryb tłustych \\
& $+100-200 \mathrm{mg}$ DHA/dobę \\
Osoby dorosłe & 2 porcje ryb/tydzień, w tym 1 porcja ryb tłustych
\end{tabular}

${ }^{1}$ najlepszy wybór - anchois, dorsz, flądra, homar, kałamarnica, krab, krewetki, langusta, łosoś, łupacz, makrela atlantycka, małże, mintaj, morszczuk, okoń, ostrygi, przegrzebki, pstrag słodkowodny, ryba maślana, sardynki, sum, śledź, tilapia i in.; ${ }^{2}$ dobry wybór - halibut, karp, makrela hiszpańska, tuńczyk biały, żabnica i in.

Tabela 2. Wykaz wybranych gatunków ryb i owoców morza zalecanych i niezalecanych w diecie kobiet planujących ciążę, kobiet ciężarnych, kobiet karmiących piersią oraz małych dzieci (MoJSKA i wspó1aut. 2017).

$\begin{array}{lll}\text { Zalecane } & \text { Dopuszczalne }{ }^{1} & \text { Niezalecane } \\ \text { Łosoś norweski, hodowlany } & \text { Karp } & \text { Miecznik } \\ \text { Szprot } & \text { Halibut } & \text { Rekin } \\ \text { Sardynki } & \text { Marlin } & \text { Makrela królewska } \\ \text { Sum } & \text { Okoń } & \text { Tuńczyk } \\ \text { Pstrag hodowlany } & \text { Żabnica } & \text { Węgorz amerykański } \\ \text { Flądra } & \text { Makrela hiszpańska } & \text { Płytecznik } \\ \text { Krewetki } & \text { Śledź } & \text { Łosoś bałtycki wędzony } \\ \text { Przegrzebki } & & \text { Szprotki wędzone } \\ \text { Ostrygi } & & \text { Śledź bałtycki wędzony } \\ \text { Dorsz } & & \text { Szczupak } \\ \text { Krab } & & \text { Panga } \\ \text { Ryba maślana } & & \text { Tilapia } \\ \text { Makrela atlantycka } & & \text { Gardłosz atlantycki }\end{array}$

Morszczuk

Langusta

${ }^{1}$ od czasu do czasu w ograniczonej ilości (maksymalnie 1 porcja/tydzień) 
Tabela 3. Zawartość tłuszczu ogółem, wielonienasyconych kwasów tłuszczowych (PUFA) oraz kwasów eikozapentaenowego (EPA) i dokozaheksaenowego (DHA) w $100 \mathrm{~g}$ części jadalnych najczęściej spożywanych w Polsce gatunków ryb i ich przetworów (KUNACHOwICZ i współaut. 2017).

\begin{tabular}{lcccc}
\hline \multirow{2}{*}{ Nazwa produktu } & Zawartość tłuszczu & Zawartość PUFA & Zawartość DHA & \multicolumn{2}{c}{ Zawartość EPA } \\
& $(\mathrm{g})$ & $(\mathrm{g})$ & $(\mathrm{g})$ & 0,12 \\
\hline Mintaj świeży & 0,6 & 0,22 & 0,62 & 0,06 \\
Śledź świeży & 10,7 & 1,87 & 0,89 & 0,96 \\
Śledź solony & 15,4 & 2,67 & 0,63 & 0,68 \\
Śledź w oleju & 26,5 & 6,67 & 1,12 & 0,63 \\
Makrela świeża & 11,9 & 2,63 & 1,70 & 1,00 \\
Makrela wędzona & 15,5 & 3,79 & 0,10 & 0,90 \\
Sardynka świeża & 9,6 & 1,6 & 0,12 & 0,06 \\
Dorsz świeży & 0,7 & 0,22 & 2,15 & 0,71 \\
Łosoś świeży & 13,6 & 4,79 & 0,93 & 0,34 \\
Łosoś wędzony & 8,4 & 1,94 & 0,08 & 0,08 \\
Karp świeży & 4,2 & 0,70 & 1,76 & 0,60 \\
Pstrag tęczowy świeży & 9,6 & 3,15 & 0,32 & 0,17 \\
Morszczuk świeży & 2,2 & 0,75 & 0,68 & 0,32 \\
Tuńczyk świeży & 4,6 & 1,36 & 0,14 & 0,01 \\
Tuńczyk w oleju & 9,0 & 4,53 & & \\
\hline
\end{tabular}

\section{KORZYŚCI WYNIKAJACE ZE SPOŻYCIA RYB}

\section{WIELONIENASYCONE KWASY TŁUSZCZOWE N-3}

Ryby, zwłaszcza morskie, oraz produkty rybne, ze względu na zawartość długołańcuchowych wielonienasyconych kwasów tłuszczowych (ang. long chain polyunsaturated fatty acids, LC-PUFA), zalecane sa w diecie osób zdrowych (Tabela 3). Jest to grupa produktów bogatych w kwasy tłuszczowe z rodziny n-3, czyli kwas eikozapentaenowy (EPA, C20:5) i dokozaheksaenowy (DHA, C22:6).

Kwasom thuszczowym n-3 przypisuje się wiele właściwości prozdrowotnych:

- obniżenie ryzyka rozwoju choroby niedokrwiennej serca (ChNS) oraz częstości występowania choroby wieńcowej, udarów i zgonów w następstwie ChNS ( $\mathrm{HE}$ i współaut. 2004, Esc/EAs 2016, LANDS 2016);

- zmniejszenie częstości występowania przewlekłych chorób o podłożu zapalnym, m.in. reumatoidalnego zapalenia stawów, wrzodziejacego zapalenia jelita grubego, łuszczycy i migrenowego bólu głowy (MOJSKA i współaut. 2017);

- udział w profilaktyce i leczeniu cukrzycy typu 2 (FAO 2010, EFSA 2010) oraz nadwagi i otyłości (EFSA 2010);

- obniżenie ryzyka zachorowania na raka jelita grubego, prostaty, piersi i śluzówki macicy (FAO 2010, KANTOR i współaut. 2014, BRASKY i współaut. 2015);

- obniżenie ryzyka rozwoju choroby Alzheimera, demencji (MOHAJERI i współaut. 2015), a także poprawę funkcji poznawczych zarówno u osób zdrowych w średnim wieku, jak i wśród osób chorych (EFSA 2010, YURKO-MAURO i współaut. 2015).

Wielu autorów sugeruje, że działanie przeciwnowotworowe kwasów $n-3$ wiąże się $z$ ich wpływem na właściwości fizykochemiczne błoń komórkowych (wzrost płynności i przepuszczalności) oraz działaniem przeciwzapalnym, antyoksydacyjnym i immunomodulujacym.

Ponadto udowodniono działanie antydepresyjne kwasów $z$ rodziny $n-3$. Spożywanie ich $\mathrm{W}$ odpowiedniej ilości wiąże się $Z$ obniżeniem ryzyka wystapienia depresji (GROsso i współaut. 2016), w tym depresji poporodowej (PARKER i współaut. 2015, MARKHUS i współaut. 2013). Antydepresyjny efekt działania kwasów n-3 związany jest $z$ ich właściwościami przeciwzapalnymi, neuroprotekcyjnymi i z modulacja neuro-endokrynna.

Długołańcuchowe wielonienasycone kwasy tłuszczowe $z$ rodziny $n-3$ odgrywaja kluczowa rolę $\mathrm{w}$ prawidłowym rozwoju w okresie prenatalnym, m.in. optymalizuja czas trwania ciąży, zapobiegają przedwczesnemu porodowi oraz obniżaja ryzyko urodzenia noworodka $z$ niska masa urodzeniowa (EFSA 2010, CARLSON i współaut. 2013). 
PAWLIK i współaut. (2011) wykazali, że u dzieci urodzonych przedwcześnie występowało obniżone stężenie DHA w osoczu krwi; w pierwszych godzinach życia dzieci urodzonych w terminie jego stężenie wynosiło 164,7 $\mu \mathrm{mol} / 1$, natomiast u dzieci urodzonych przedwcześnie zaledwie 15,9 $\mu \mathrm{mol} / 1$. W mózgu i siatkówce oka stężenie kwasu DHA jest stosunkowo duże, co jest wiazane $z$ jego wpływem na prawidłowy rozwój układu nerwowego i funkcji poznawczych u niemowląt i małych dzieci, w tym mowy i narządu wzroku (EFSA 2008, 2014). Łożysko i płód syntetyzują bardzo małe ilości LC-PUFA, dlatego musza być one dostarczanie $z$ organizmu matki. W trzecim trymestrze ciąży następuje znaczne nasilenie gromadzenia kwasu DHA w tkankach płodu, co skorelowane jest $z$ intensywnym rozwojem układu nerwowego. To właśnie wówczas należy zwracać szczególna uwagę na prawidłowa podaż tego składnika $z$ dieta (REES i współaut. 2014). Niedostateczne spożycie żywności pochodzenia morskiego $(<340 \mathrm{~g} /$ tydz.) przez matki wiąże się ze zwiększonym ryzykiem wystapienia niższego ilorazu inteligencji werbalnej oraz gorszych wyników zachowań prospołecznych u dzieci, a także rozwoju społecznego w zakresie motoryki i komunikacji (HIBBELN i współaut. 2007). Holenderscy naukowcy stwierdzili zależność między większym spożyciem LC-PUFA n-3 w okresie ciąży a rzadszym wystapieniem problemów emocjonalnych u dzieci (STEENWEG-DE GRAAFF 2015). Działanie kwasów $z$ rodziny $\mathrm{n}-3$, szczególnie EPA, ma istotny udział w leczeniu zespołu nadpobudliwości $z$ deficytem uwagi (ADHD) (COOPER 2016). HIBBELN i współaut. (2006) podkreślają, że małe spożycie ryb w czasie ciaży i w okresie karmienia piersią może skutkować predyspozycjami do agresji i depresji u dzieci, jednocześnie twierdząc, że zapewnienie optymalnego spożycia kwasów tłuszczowych n-3 we wczesnym okresie rozwoju organizmu zmniejsza ryzyko zaburzeń zachowania emocjonalnego wśród dzieci.

Korzystny wpływ LC-PUFA n-3 wiąże się z obniżeniem ryzyka rozwoju alergii u dzieci poprzez hamowanie nadmiernej odpowiedzi immunologicznej i osłabienie procesów zapalnych (EFSA 2014, BEST i współaut. 2016). Niskie stężenie wymienionych kwasów w mleku matki i diecie małych dzieci może być przyczyna rozwoju astmy, alergicznego nieżytu nosa, a także atopowego zapalenia skóry u niemowlat i małych dzieci (NAFSTAD i współaut. 2003, EFSA 2004b). Stwierdzono, iż kobiety, które spożywały ryby w czasie ciąży i karmienia piersia szybciej decydowały się na wprowadzanie tego produktu do diety swoich dzieci (NAFSTAD i współaut. 2003).

\section{PEŁNOWARTOŚCIOWE BIAŁKO}

Mięso ryb pod względem jakości oraz ilości białka nie ustępuje mięsu zwierząt rzeźnych i drobiu. Zawartość białka w zależności od gatunku ryby wynosi $13-24 \%$, $z$ czego jedynie 3-5\% stanowi niepełnowartościowe białko tkanki łącznej, podczas gdy w mięsie zwierząt rzeźnych wartość ta może sięgać nawet 16\% (GAWECKI i WoźNIEWICZ 2010). Skład aminokwasowy białka mięsa ryb jest bardzo korzystny pod względem żywieniowym i przewyższa skład białka wzorcowego ustalonego przez Komitet Ekspertów FAO/WHO w 1991 r. (FAO/WHO 1991). Potwierdzaja to badania POLAKA-JUSZCZAK i ADAMCZYK (2009), które wykazały, iż zawartość niezbędnych aminokwasów występujących w białku ryb z Zalewu Wiślanego była wyższa niż w białku wzorcowym. Szczególnie korzystne były ilości lizyny oraz metioniny i cysteiny, które w stosunku do białka wzorcowego, wynosily od 145 do $240 \%$. Dodatkowo, białko ryb jest łatwostrawne, gdyż jego strawność wynosi 97\% (BORUCKA i WIECZOREK 2003). Warto też wspomnieć, iż podaż białka $z$ mięsa ryb jest duża przy jednocześnie małej podaży energii. Najbogatsze w białko sa ryby świeże, szczególnie halibut, sardynka oraz tuńczyk (zawieraja ok. 20\% białka) (KunACHOWICZ i współaut. 2017).

Przy jednoznacznych, niewątpliwych korzyściach zdrowotnych wynikajacych ze spożycia mięsa ryb, w ostatnich latach zaobserwowano wyraźny wzrost częstości występowania objawów alergii pokarmowej o różnym stopniu nasilenia wywołanej białkami rybimi (KHAN i współaut. 2011). Pierwszym znanym alergenem była parwalbumina, białko wyizolowane $z$ tkanki mięśniowej dorsza. Białko to obecne jest także w innych rybach, dlatego osoby uczulone na jeden gatunek, powinny unikać spożywania wszystkich pozostałych. Obróbka termiczna tylko w nieznacznym stopniu zmniejsza alergenność tego białka (JĘDRUSEK-GOLIŃSKA 2014). $\mathrm{Za}$ występowanie objawów alergii w Europie odpowiadaja głównie: dorsz bałtycki, łosoś atlantycki, flądra, śledź, tuńczyk i karp (LOPATA i współaut. 2010).

\section{WITAMINY}

Ryby, zarówno chude, jak i tłuste, sa dobrym źródłem witamin. Ryby tłuste (śledź, łosoś, pstrag, makrela) zawierają znaczne ilości witaminy A i witaminy D (Tabela 4), natomiast ryby chude (szczupak, okoń) witamin $z$ grupy $B$.

Niedobór witaminy D jest ważnym i powszechnym problemem zdrowotnym w Polsce (RusińsKA i współaut. 2018). Źródłem tej witaminy dla człowieka, poza endogenną synteza skórna, moga być tłuste ryby i 
Tabela 4. Zawartość witaminy D w wybranych gatunkach ryb i ich przetworach (KUNACHOwICZ i współaut. 2017).

\begin{tabular}{lc}
\hline Nazwa produktu & Zawartość witaminy D $(\mu \mathrm{g} / 100 \mathrm{~g}$ części jadalnych) \\
\hline Śledź w oleju & 20,2 \\
Śledź świeży & 19,0 \\
Pstrag tęczowy, świeży & 13,6 \\
Łosoś świeży & 13,0 \\
Łosoś wędzony & 13,0 \\
Sardynka świeża & 11,0 \\
Śledź solony & 9,2 \\
Makrela wędzona & 8,4 \\
Tuńczyk świeży & 7,2 \\
Makrela świeża & 5,0 \\
Karp świeży & 5,0 \\
Halibut świeży & 5,0 \\
Dorsz świeży & 1,0 \\
Mintaj świeży & 0,1 \\
\hline
\end{tabular}

oleje rybie. Jednak pokrycie zapotrzebowania na tę witaminę poprzez spożycie ryb wydaje się niemożliwe. Według szacunków przeprowadzonych przez MALESE-CIEĆWIERZ i Usydus (2015), żeby dostarczyć dziennie $20 \mu g$ witaminy D należałoby rocznie zjeść około $68 \mathrm{~kg}$ śledzia lub $26 \mathrm{~kg} ł o s o s i a, ~ n a-$ tomiast rzeczywiste roczne spożycie wynosi odpowiednio około 1,3 i 0,4 kg/osobę. Znaczenie witaminy $\mathrm{D} w$ regulacji homeostazy wapnia i fosforanów oraz metabolizmie tkanki kostnej znane jest od dziesięcioleci. Natomiast w ostatnich latach prowadzono szereg badań, które dowodza, iż witamina ta wykazuje również działanie plejotropowe, uczestniczac $w$ regulacji kilkuset genów genomu człowieka. Wykazano, że kalcytriol wspomaga proliferację i różnicowanie komórek należących do układu immunologicznego. Niedobór witaminy D częściej występuje u pacjentów $z$ chorobami zapalnymi jelit, reumatoidalnym zapaleniem stawów i w chorobach tarczycy. Wiele badań wskazuje na istnienie związku między niskim stężeniem 25(OH)D w surowicy krwi a zwiększonym ryzykiem zachorowania na stwardnienie rozsiane (GALANT i współaut. 2016). Wykazano dłuższa przeżywalność pacjentów $z$ przewlekła choroba nerek, którzy przyjmowali suplementy witaminy $\mathrm{D}$, a nie byli poddawani dializoterapii oraz mniejsza śmiertelność $z$ przyczyn chorób sercowo-naczyniowych u pacjentów poddawanych hemodializie i jednocześnie przyjmujacych suplementy witaminy $\mathrm{D}$, w stosunku do osób niesuplementujacych swojej diety (WAWRZYNIAK i współaut. 2015).
Wyniki licznych badań świadczą, że odpowiednie stężenie witaminy D stanowi ważny czynnik w prewencji rozwoju insulinooporności oraz cukrzycy typu 1 i 2 . Ważnym jest zapewnienie odpowiedniej podaży (suplementację) tej witaminy już od pierwszego roku życia. W badaniu obejmujacym grupę ponad 12 tysięcy dzieci, stwierdzono zmniejszone ryzyko wystapienia cukrzycy typu 1 o $80 \%$ u tych dzieci, które otrzymywały suplementy witaminy $\mathrm{D}$ w pierwszym roku życia, w stosunku do ryzyka populacyjnego (GALANT i współaut. 2016).

Badania epidemiologiczne wykazały, że witamina D ma także działanie przeciwnowotworowe. Prawidłowy stan zaopatrzenia organizmu w witaminę D zmniejsza ryzyko rozwoju nowotworów, m.in. okrężnicy, piersi, jajnika, trzustki, prostaty, nerek, mózgu, jelita grubego i białaczki (RUSIŃSKA i współaut. 2018).

W wielu badaniach stwierdzono zwiazek pomiędzy niskim stężeniem witaminy $\mathrm{D}$ w osoczu a zwiększonym ryzykiem wystapienia chorób ośrodkowego układu nerwowego, w szczególności pogorszeniem funkcji poznawczych, wyższym ryzykiem choroby Alzheimera i demencji (WAWRZYNIAK i współaut. 2015).

\section{SKŁADNIKI MINERALNE}

Ryby, ich przetwory oraz owoce morza sa produktami bogatymi w składniki mineralne. Ilość niektórych makroelementów, takich jak fosfor, potas czy magnez w rybach jest większa niż w surowcach mięsnych, a w przypadku ryb drobnoościstych (śledź) i 
marynat również większa jest w nich zawartość wapnia (GAWECKI i WOŹNIEWICZ 2010). Do wartych wyróżnienia mikroelementów należą przede wszystkim fluor, jod (szczególnie gatunki ryb morskich) i selen. Zawartość jodu w filetach ryb morskich jest zróżnicowana. Najwięcej tego składnika stwierdzono w dorszu świeżym (110 $\mu \mathrm{g} / 100$ g części jadalnych) i mintaju (103 $\mu \mathrm{g} / 100 \mathrm{~g}$ części jadalnych), natomiast najmniej w okoniu (4 $\mu \mathrm{g} / 100 \mathrm{~g}$ części jadalnych) i karpiu (1,5 $\mathrm{\mu g} / 100 \mathrm{~g}$ części jadalnych) (KunACHOWICZ i współaut. 2017). Ryby, w porównaniu do mięsa zwierząt rzeźnych, zawieraja kilkakrotnie więcej fluoru, przy czym ryby morskie odznaczają się większą jego zawartościa niż ryby słodkowodne, średnio jest to 5,1 mg/ kg świeżej masy. Pierwiastek ten przede wszystkim kumuluje się w skórze i ościach ryby (KoŁAKOWSKA i KoŁAKOWSKI 2001). Badania nad zawartościa makro- i mikroelementów w produktach rybnych wyprodukowanych i dostepnych na polskim rynku przeprowadzone przez Morski Instytut Rybacki w Gdyni (POLAK-JUSZCZAK i USYDUS 2006) wykazały, że średnia zawartość fluoru w konserwie ze szprotów wynosiła 20,4 mg/ $\mathrm{kg}$, podczas gdy wystarczajace dobowe spożycie (norma na poziomie AI; ang. adequate intake) tego pierwiastka równe jest $3 \mathrm{mg}$ dla kobiet i $4 \mathrm{mg}$ dla mężczyzn (JAROsz 2017a). Badane konserwy zawierały 0,58 mg/kg jodu i 0,11 mg/kg selenu, podczas gdy wystarczajace spożycie jodu przez osoby dorosłe wynosi $0,15 \mathrm{mg} /$ dobe, a zalecane spożycie (ang. recommended dietary allowance, RDA) selenu 0,055 mg/dobę (JAROsz 2017a).

Produkty rybne są ważnym źródłem selenu. Pierwiastek ten odgrywa istotna rolę $\mathrm{w}$ procesach detoksykacyjnych organizmu, wchodzi w skład selenoenzymów chroniacych tkanki przed uszkodzeniami oksydacyjnym. Dodatkowo, selenoenzymy wpływaja na metabolizm metylortęci obniżajacc, jako naturalny antagonista, jej toksyczność. Duże powinowactwo metylortęci do selenu sprawia, iż tworza się trwałe, całkowicie nieprzyswajalne przez organizm połączenia (MANIA i współaut. 2012). Udowodniono, że zawartość selenu w racji pokarmowej opóźnia pojawienie się niektórych objawów neurologicznych przy długotrwałym narażeniu na zwiazki metylortęciowe (HEATH i współaut. 2010). Z drugiej strony, metylortęć hamuje korzystny wpływ selenu na organizm. Dlatego sugeruje się, aby wybierać ryby słonowodne, w których zawartość selenu jest wyższa niż metylortęci. Selen wykazuje także działanie antydepresyjne i przeciwnowotworowe (szczególnie w odniesieniu do nowotworów płuc, skóry i prostaty). Odpowiedni stan odżywienia tym pierwiastkiem hamuje rozwój chorób układu krążenia, układu odpornościowego, chorób tarczycy czy zaburzeń reprodukcji (BYKOwSKI 2011). Jednak zarówno niedobór, jak i nadmiar tego pierwiastka wywiera szkodliwe działanie na organizm, co wynika $z$ waskkiego marginesu bezpieczeństwa.

Niektóre gatunki ryb i ich przetwory, a także owoce morza moga być dobrym źródłem cynku, mikroelementu również istotnego dla zdrowia. W rybach wędzonych średnie stężenie cynku mieści się w zakresie 4,0-32,5 mg/kg. Najmniej tego pierwiastka zawiera wędzony łosoś norweski (4,0 mg/ $\mathrm{kg})$, najwięcej szprot $(32,5 \mathrm{mg} / \mathrm{kg})$ (PoLAK-JUSZCZAK 2008). Spośród ryb świeżych bogate w cynk sa śledź i węgorz, które zawieraja odpowiednio $11,2 \mathrm{mg} / \mathrm{kg}$ i $17,5 \mathrm{mg} / \mathrm{kg}$ tego pierwiastka (KUNACHOWICZ i współaut. 2017). Wśród owoców morza pod względem zawartości cynku wyróżnia się mięso kraba (97 $\mathrm{mg} / \mathrm{kg}$ ) i homara $(42,7 \mathrm{mg} / \mathrm{kg}$ ) (RoGACKA i współaut. 2003). Porcja 100 g kraba pokrywa dzienne zalecane spożycie (norma RDA) na ten pierwiastek zarówno dla kobiet, jak i mężczyzn, które wynosi odpowiednio 8 mg i 11 mg (JAROSZ 2017a).

Należy podkreślić, że dieta uboga w cynk, zwłaszcza w wieku rozwojowym, może skutkować niedostatecznym rozwojem gonad męskich, impotencją i pogorszeniem parametrów nasienia (JEZNACH-STEINHAGEN i CZERWONOGRODZKA-SENCZYNA 2013). Udowodniono, iż cynk wpływa także na prawidłowy proces owulacji i cykl menstruacyjny kobiety oraz metabolizm hormonów żeńskich. Jego niewystarczająca podaż może także prowadzić do nieprawidłowego kształtowania się płodu i przedwczesnego porodu (BOJANOWSKA i KOSTECKA 2018).

\section{ZAGROŻENIA WYNIKAJĄCE ZE SPOZYCIA RYB}

Ryby i ich przetwory oraz owoce morza, podobnie jak inne produkty spożywcze, zawierają substancje niepożądane w żywieniu człowieka. Ich obecność wynika głównie $z$ zanieczyszczenia środowiska wodnego, dlatego też ryby stanowią wskaźnik skażenia środowiska ich bytowania. Ryby i inne organizmy wodne sa zdolne do kumulowania metali ciężkich, przede wszystkim rtęci, ołowiu, kadmu $i$ arsenu. Sa to nie tylko pierwiastki toksyczne, ale wpływaja one również niekorzystnie na przyswajalność składników mineralnych niezbędnych dla organizmu człowieka, takich jak magnez, żelazo, cynk, miedź, selen.

\section{METYLORTĘĆ}

Rtęć może występować w środowisku w postaci elementarnej oraz połaczeń nieorga- 
nicznych i organicznych, przy czym te drugie charakteryzuja się największa toksycznością. Do głównych źródeł narażenia człowieka na organiczne związki rtęci należy żywność pochodzenia morskiego, w tym ryby i owoce morza (EFSA 2004a).

Szacuje się, że $75-95 \%$ rtęci w rybach i owocach morza ma formę metylortęci (MeHg). Stężenie jej w rybach jest bardzo zróżnicowane i zależy od wielu czynników. Ważny jest aspekt geograficzny zwiazany $z$ obszarem bytowania określonego gatunku ryby i jakościa dostępnego pokarmu, jak również czynnik biologiczny wynikajacy $z$ cech gatunkowych, takich jak wielkość organizmu i ilość tkanki mięśniowej oraz mechanizm wchłaniania. Duże drapieżne ryby, takie jak miecznik, rekin czy tuńczyk, gromadza większe ilości metylortęci w związ$\mathrm{ku} \mathrm{z}$ dużym spożyciem wynikającym $\mathrm{z}$ długiego okresu życia (КоT i współaut. 2016). Metylortęć, która dostaje się do organizmu człowieka głównie $z$ pożywieniem $w$ wyniku spożywania ryb i ich przetworów, jest szczególnie niebezpieczna dla kobiet ciężarnych oraz małych dzieci. Okres połowicznego wydalania tej silnej neurotoksyny, w porównaniu do nieorganicznych związków rtęci, jest dwukrotnie dłuższy $\mathrm{i}$ wynosi ponad $70 \mathrm{dni}$ (Chmelnicka 2005). Głównymi miejscami kumulacji rtęci $\mathrm{w}$ organizmie człowieka jest kora mózgowa i móżdżek (KoT i współaut. 2016). W przypadku kobiet $\mathrm{w}$ ciaży metylortęć z łatwościa przenika barierę krew-łożysko i gromadząc się w mózgu płodu, uszkadzając przede wszystkim ośrodkowy układ nerwowy. Przy dużych dawkach metylortęć powoduje bardziej rozległe uszkodzenia, podobne do objawów porażenia mózgowego (MANIA i współaut. 2012). Zawartość MeHg w krwinkach płodu jest o około 30\% większa niż w krwinkach matek (CHMIELNICKA 2005). Nawet stosunkowo małe ilości dostajace się do pło$\mathrm{du}$ w czasie ciaży moga powodować u dzieci poważne zaburzenia w chodzeniu, mówieniu, słyszeniu czy pisaniu. Zauważono również korelacje pomiędzy masa urodzeniowa dziec$\mathrm{ka}$ a stężeniem rtęci we krwi pępowinowej oraz łożysku i błonie płodowej (SUPREwICZ i KozIKOWSKA 2014). Ponadto, niemowlęta moga być narażone na działanie metylortęci w wyniku karmienia piersia. Environmental Protection Agency (EPA) w USA szacuje, że na świecie około 7 milionów kobiet i dzieci regularnie spożywa ryby zanieczyszczone metylortęcia powyżej poziomu uznawanego za bezpieczny (LEŚNIEWSKA i współaut. 2009).

Niektórzy badacze sugeruja, że zwiazzki rtęci wpływaja na powstawanie lub zaostrzenie objawów stwardnienia rozsianego, stwardnienia zanikowego bocznego, choroby Alzheimera i choroby Parkinsona (CLARKSON i współaut. 2003). Dyskusyjnym wciąż jest powiązanie zatrucia rtęcia $i$ jej związkami a występowaniem autyzmu dziecięcego (PALMER i współaut. 2009).

Eksperci Europejskiego Urzędu ds. Bezpieczeństwa Żywności (EFSA 2012a) oraz Wspólnego Komitetu Ekspertów FAO/WHO ds. Dodatków do Żywności wydali opinię dotycząca występowania rtęci w żywności i zatwierdzili tolerowane tygodniowe pobranie (ang. tolerable weekly intake, TWI) na poziomie 4,0 $\mathrm{\mu g} / \mathrm{kg}$ masy ciała/tydzień dla związków nieorganicznych rtęci oraz nie więcej niż 1,3 $\mathrm{\mu g} / \mathrm{kg}$ masy ciała/tydzień dla metylortęci (EFSA 2012a).

Maksymalne dopuszczalne poziomy metali ciężkich w żywności zostały opublikowane w Rozporządzeniu Komisji (WE) nr 1881/2006 z późniejszymi zmianami. Najwyższy dopuszczalny poziom rtęci ustalono jedynie dla ryb i produktów rybołówstwa $\mathrm{w}$ zakresie od 0,5 do $1,0 \mathrm{mg} / \mathrm{kg}$ świeżej masy (w zależności od gatunku) oraz suplementów diety $0,1 \mathrm{mg} / \mathrm{kg}$ (ROZPORZĄDZENIE 1881, 2006).

\section{KADM}

Kadm wykazuje działanie mutagenne, genotoksyczne i rakotwórcze (MARTYNOWICZ i SKOCZYŃSKA 2004). Zatrucia ostre dużymi dawkami kadmu zdarzaja się rzadko, natomiast zatrucia przewlekłe prowadza do zaburzeń układu pokarmowego, oddechowego, nerwowego i krążenia krwi. Pierwiastek ten gromadzi się głównie w watrobie i nerkach (KREJPCIO i KRÓL 2014). Wyniki kilkuletnich badań monitoringowych prowadzonych zarówno w Polsce, jak i w innych krajach Unii Europejskiej wykazują coraz wyższe zanieczyszczenie kadmem glonów morskich, ryb i owoców morza. Jednak uwzględniając spożycie poszczególnych grup produktów, największy udział w całkowitym pobraniu kadmu z żywnościa maja zboża i produkty zbożowe, warzywa oraz ziemniaki (WOJCIECHOWSKA-MAZUREK i współaut. 2010). Na początku 2009 r. Europejski Urząd ds. Bezpieczeństwa Żywności określił wartość tolerowanego tygodniowego pobrania kadmu na poziomie $2,5 \mathrm{\mu g} / \mathrm{kg}$ masy ciała/tydzień. Wartość ta jest 2,8 razy niższa od wartości tymczasowego tolerowanego tygodniowego pobrania (ang. provisional tolerable weekly intake PTWI) ustalonej w 1988 r. i potwierdzonej w 2005 r. przez Wspólny Komitet Ekspertów FAO/ WHO ds. Dodatków do Żywności, wynoszacej $7 \mu \mathrm{g} / \mathrm{kg}$ masy ciała/tydzień (EFSA 2009). Zgodnie $\mathrm{z}$ obowiazującym ustawodawstwem najwyższy dopuszczalny poziom kadmu wynosi $0,05 \mathrm{mg} / \mathrm{kg}$ dla mięsa ( $\mathrm{z}$ wyłączeniem podrobów); $0,2 \mathrm{mg} / \mathrm{kg}$ dla warzyw liściastych, otrębów, ryżu i nasion soi; od 0,05 
$\mathrm{mg} / \mathrm{kg}$ do $0,3 \mathrm{mg} / \mathrm{kg}$ dla ryb w zależności od gatunku; oraz od $0,5 \mathrm{mg} / \mathrm{kg}$ do $1,0 \mathrm{mg} /$ $\mathrm{kg}$ dla owoców morza (ROZPORZĄDZENIE 1881 2006).

\section{RODZINA DIOKSYN}

Rodzina dioksyn to duża grupa zwiąków organicznych $z$ grupy polichlorowanych węglowodorów. Powstaja jako przemysłowe produkty uboczne m.in. podczas spalania, przy niedostatecznym dopływie tlenu, komunalnych i przemysłowych odpadów zawierających chlor, podczas pożarów lasów, spalania olejów napędowych zawierajacych chlor oraz w zwykłych paleniskach domowych. Dioksyny sa stosunkowo trwałe, dobrze rozpuszczaja się w tłuszczach, natomiast słabo w wodzie. Występuja powszechnie $\mathrm{w}$ środowisku naturalnym i odznaczają się wysoka zdolnościa do kumulacji w łańcuchu pokarmowym. Przedostaja się do środowiska wodnego głównie $z$ atmosfery oraz ze ściekami podczas $\mathrm{m}$. in. produkcji papieru i celulozy, w której wykorzystywane sa chloroorganiczne zwiazki aromatyczne. Kumuluja sie w osadach dennych i stad dostaja się do organizmów ryb. Dioksyny sa obecne w rybach i przetworach rybnych $\mathrm{w}$ większych stężeniach niż $\mathrm{w}$ innych produktach żywnościowych.

Dioksyny sa substancjami silnie toksycznymi, osłabiaja układ odpornościowy, zaburzaja gospodarkę hormonalna, wykazuja działanie mutagenne, kancerogenne i teratogenne (KREJPCIO i KRÓL 2014). Zawartość dioksyn w żywności jest także regulowana przez Rozporządzenie Komisji (UE) nr 1259 (ROZPORZĄZENIE 1259 2011) zmieniajace rozporzaczzenie $\mathrm{nr} 1881 / 2006 \mathrm{w}$ odniesieniu do najwyższych dopuszczalnych poziomów w środkach spożywczych dioksyn, polichlorowanych bifenyli o działaniu podobnym do dioksyn i polichlorowanych bifenyli o działaniu niepodobnym do dioksyn. Wyniki raportu z 2017 r. badań kontrolnych (przeprowadzonych przez Krajowe Laboratorium Referencyjne ds. Dioksyn, Zakład Radiobiologii PIWet-PIB, Puławy) dotyczących stężeń dioksyn, furanów, dioksypodobnych polichlorowanych bifenyli (PCB) i niedioksypodobnych PCB w tkankach zwierzat i w produktach pochodzenia zwierzęcego, wykazały niskie, nieprzekraczajace zawartości dopuszczalnych (w tym w rybach bałtyckich oraz $z$ akwakultury) stężenia tych zwiąków, a tym samym niestanowiace ryzyka dla zdrowia ludzi (PIWET-PIB 2018).

W 2018 r. Europejski Urzad ds. Bezpieczeństwa Żywności (EFSA) wyznaczył nowy poziom dopuszczalnego tygodniowego spożycia (TWI) dioksyn i dioksynopochodnych
PCB obecnych w żywności równy $2 \mathrm{pg} / \mathrm{kg}$ masy ciała. Jest on siedem razy niższy od dotychczasowego unijnego limitu ustalonego przez Komitet Naukowy ds. Żywności Komisji Europejskiej w 2001 r. (EFSA 2018).

\section{POLICHLOROWANE BIFENYLE}

Polichlorowane bifenyle (PCB) obejmuja około 200 związków, z których część wykazuje zbliżone do dioksyn działanie toksyczne. Zwiazki te powstaja podczas pożarów lasów, spalania materii organicznej i odpadów oraz uwalniaja się do środowiska ze zużytych urządzeń termicznych, m.in. kondensatorów i transformatorów. Do środowiska wodnego PCB przedostaja się głównie ze ściekami przemysłowymi i komunalnymi $z$ obszarów zanieczyszczonych, $z$ opadami atmosferycznymi oraz $\mathrm{z}$ farbami używanymi do malowania statków i łodzi. Wiele $z$ nich deponuje się w mułach i osadach dennych (ROSIŃSKA I DABROWSKA 2011). PCB, podobnie jak dioksyny, sa dobrze rozpuszczalne w tłuszczach i mają zdolność kumulacji we wszystkich ogniwach łańcucha pokarmowego. Do głównych źródeł PCB w diecie należa produkty zwierzęce (ryby, mięso, mleko), których udział $\mathrm{w}$ całkowitym pobraniu stanowi nawet $90 \%$. Na uwage zasługuja ryby morskie i słodkowodne, które zawieraja znacznie wyższe stężenia tych zwiazków niż inne grupy produktów spożywczych. Ich zawartość w produktach jest ścisłe zwiazana ze skażeniem środowiska naturalnego.

W Polsce już od ponad 40 lat Państwowy Instytut Weterynaryjny w Puławach prowadzi regularnie badania zawartości PCB w tkankach zwierzat i żywności pochodzenia zwierzęcego. Przeciętne pobranie tych związków $z$ dieta $w$ krajach Unii Europejskiej nie przekracza dopuszczalnych poziomów, regulowanych przez Rozporzadzenie Komisji (UE) nr 1259/2011 z dnia 2 grudnia $2011 \mathrm{r}$. zmieniajace rozporzadzenie (WE) $\mathrm{nr} 1881 / 2006 \mathrm{w}$ odniesieniu do najwyższych dopuszczalnych poziomów w środkach spożywczych dioksyn, polichlorowanych bifenyli o działaniu podobnym do dioksyn i polichlorowanych bifenyli o działaniu niepodobnym do dioksyn (KREJPCIO i KRÓl 2014). NIEWIADOWSKA i współaut. (2012) stwierdzili obecność PCB we wszystkich badanych próbach ryb pochodzacych $z$ polskich obszarów połowowych Morza Bałtyckiego. Jednak oznaczone stężenia tych związków nie stanowiły zagrożenia dla zdrowia konsumentów, ponieważ były niższe od dopuszczalnych i uznanych za bezpieczne. 


\section{WIELOPIERŚCIENIOWE WEGLOWODORY AROMATYCZNE} (WWA)

Jest to duża grupa zwiazków, do których zalicza się m.in. benzo[a]piren (BaP), benzo[a]antracen, naftalen i chryzen. Zwiazki te powstaja w procesach termicznego rozkładu materii organicznej. Wykazują zdolność do kumulacji w organizmie człowieka, a wiele $Z$ nich ma działanie genotoksyczne, mutagenne i rakotwórcze. Do żywności WWA przenikaja z powietrza, gleby i wody, a także moga powstawać w procesach termicznej jej obróbki, podczas pieczenia, smażenia, grillowania oraz wędzenia. Szczególnie niekorzystne jest grillowanie lub wędzenie produktów bezpośrednio nad płomieniem lub żarem, kiedy ściekajacy tłuszcz ulega degradacji, a powstałe WWA osadzaja się na produkcie (KREJPCIO i KRÓL 2014). Ponadto, ryby moga być narażone na obecność tych zwiąków w wodzie i osadach dennych (PIETRZAK-FIEĆKO i współaut. 2015).

Największy udział w dostarczaniu WWA maja produkty pochodzenia zwierzecego bogate $w$ tłuszcz (mięso i ryby) oraz oleje roślinne. Przeciętne pobranie związków $z$ grupy WWA w krajach UE nie przekracza dopuszczalnych poziomów (KREJPCIO i KRÓL 2014).

Od 1 września 2014 r. obowiazuja nowe najwyższe dopuszczalne poziomy benzo[a]pirenu oraz sumy benzo[a]pirenu, chryzenu, benzo[a]-antracenu i benzo[b]fluorantenu w produktach spożywczych - wynosza one odpowiednio 2,0 i $12,0 \mu \mathrm{g} / \mathrm{kg}$ dla ryb wędzonych oraz 5,0 i 30,0 $\mathrm{\mu g} / \mathrm{kg}$ dla szprot wędzonych (ROZPORZĄDZENIE 835, 2011).

Stosowane w ostatnim okresie kontrolowane sposoby wędzenia doprowadziły do zmniejszenia ilości benzo[a]pirenu w rybach wędzonych. Według badań PIETRZAK-FIEĆKO i współaut. (2015) największą średnia zawartość BaP stwierdzono w mięsie karpia $(1,03$ $\mu \mathrm{g} / \mathrm{kg})$ i sielawy $(0,85 \mu \mathrm{g} / \mathrm{kg})$. Średnia zawartość sumy czterech wskaźnikowych WWA była zróżnicowana i mieściła się w zakresie od $2,73 \mu \mathrm{g} / \mathrm{kg}$ miessa pstraga do 8,32 $\mu \mathrm{g} /$ $\mathrm{kg}$ mięsa karpia. W żadnej $z$ analizowanych próbek mięsa pstraga, karpia, sielawy i węgorza nie zostały przekroczone obowiazujace najwyższe dopuszczalne poziomy zawartości WWA w środkach spożywczych.

\section{ZANIECZYSZCZENIA RYB STWIERDZANE W RAMACH SYSTEMU RASFF}

W ostatnich latach w ramach systemu wczesnego ostrzegania o niebezpieczeństwie pochodzacym $z$ żywności lub pasz (ang. rapid alert system for food and feed, RASFF) systematycznie rośnie liczba powiadomień alarmowych dla produktów rybołówstwa. W 2017 r. odnotowano 135 takich powiadomień (RAsfF 2018). Przyczyny powiadomień w przypadku ryb i ich przetworów sa różne, jednak największe zagrożenie stanowi wysoki poziom metali ciężkich $163 \%$ ogółu powiadomień), w tym głównie rtęci i jej najbardziej toksycznej formy metylortęci oraz w mniejszym stopniu kadmu. Na kolejnym miejscu znajduja się drobnoustroje chorobotwórcze (19\% powiadomień) i zanieczyszczenia biologiczne $(15 \%)$. Jedna $z$ powtarzajacych się przyczyn powiadomień w systemie RASFF było wykrycie w produktach zbyt dużych ilości histaminy. Zwiąek ten powstaje na skutek psucia się mięsa ryb w drodze przemian histydyny, aminokwasu obecnego w dużych ilościach zwłaszcza w rybach śledziowatych, makrelowatych, tuńczykowatych i łososiowatych (GAWECKI i WOźNIEWICZ 2010). Im wyższa temperatura, tym szybciej zachodzi proces, więc aby go opóźnić ryby i ich przetwory powinny być przechowywane w warunkach chłodniczych (FAO/WHO 2012).

\section{PODSUMOWANIE}

Ryby, przetwory rybne i owoce morza sa produktami bogatymi w wielonienasycone kwasy tłuszczowe n-3, pełnowartościowe białko oraz jod, selen i fluor, a także witaminę D. Mimo występującego ryzyka zwiazanego ze spożyciem ryb, przetworów rybnych i owoców morza, spowodowanego zanieczyszczeniem tych produktów metylortęcia i dioksynami, korzyści zdrowotne wynikajace $z$ ich umiarkowanego spożycia przewyższaja ryzyko.

\section{Streszczenie}

Ryby i owoce morza są ważnym elementem prawidłowo zbilansowanej diety, na każdym etapie rozwoju i życia człowieka. Spożywanie ryb co najmniej 2 razy w tygodniu zalecane jest przez żywieniowców na całym świecie w celu profilaktyki choroby niedokrwiennej serca i nowotworów. Jednak ze względu na istnienie ryzyka zanieczyszczenia tych produktów m.in. metylortęcia i dioksynami, dla grup wrażliwych (kobiet w ciąży, karmiących piersia oraz dzieci) wprowadzono pewne ograniczenia ich spożycia. Jednocześnie podkreśla się, że korzyści zdrowotne wynikające ze spożycia umiarkowanych ilości ryb przez kobiety w cią̇y przewyższaja ryzyko. W wielu krajach podjęto działania edukacyjne w zakresie zaleceń żywieniowych, dotyczące ograniczenia spożycia określonych gatunków ryb morskich ze względu na zawartość w nich metylortęci. Istotna wydaje się być edukacja kobiet ciężarnych, karmiących piersią oraz w wieku rozrodczym dotyczaca spożycia ryb, ich wartości odżywczej oraz wyboru odpowiednich gatunków.

\section{LITERATURA}

Best K. P., Gold M., Kennedy D., Martin J., MAKRIDES M., 2016. Omega-3 long-chain PUFA 
intake during pregnancy and allergic disease outcomes in the offspring: a systematic review and meta-analysis of observational studies and randomized controlled trials. Am. J. Clin. Nutr. 103, 128-143.

BoJANOWSKA M., KosteCKA M., 2018. Dieta $i$ styl życia jako czynniki wpływajace na płodność. Kosmos 67, 425-439.

BORUCKA I., WIECZOREK C., 2003. Ryby i bezkregowce morskie $w$ technologii gastronomicznej. [W:] Podstawy technologii gastronomicznej. ZALEWSKI S. (red.). Wyd. Naukowo-Techniczne, Warszawa, 178-181.

Brasky T. M., RODABOUgh R. J., LIU J., KURTA M. L., WiSE L. A., ORChARD T. S., COHN D. E., Belury M. A., White E., Manson J. E., NEUHOUSER M. L., 2015. Long-chain $\omega-3$ fatty acid intake and endometrial cancer risk in the Women's Health Initiative. Am. J. Clin. Nutr. $101,824-834$.

BYKOWSKI P., 2011. Żywność pochodzenia morskiego korzyści dla zdrowia konsumenta. Przem. Spoż. 12, 31-33.

Carlson S. E., Colombo J., Gajewski B. J., GuSTAFSON K. M., MUNDY D., YEAST J., GEORGIEFF M. K., MARKLEY L. A., KeRling E. H., SHADDY D. J., 2013. DHA supplementation and pregnancy outcomes. Am. J. Clin. Nutr. 97, 808-815.

CHMIELNiCKA J., 2005. Toksyczność metali i pótmetali (metaloidów). [W:] Toksykologia wspótczesna. SEŃCZUK W. (red.). Wyd. Lekarskie PZWL, Warszawa, 360-446.

Clarkson T. W., Magos L., Myers G. J., 2003. The toxicology of mercury - current exposures and clinical manifestations. N. Engl. J. Med. 349, 1731-1737.

Cooper R. E., Tye C., Kuntsi J., Vassos E., AshERSON P., 2016. The effect of omega-3 polyunsaturated fatty acid supplementation on emotional dysregulation, oppositional behaviour and conduct problems in ADHD: A systematic review and meta-analysis. J. Affect. Disord. 190, 474-482.

EFSA, 2004a. Scientific opinion of the Panel on Contaminants in the Food Chain on a request from the Commission related to mercury and methylmercury in food. EFSA J. 34, 1-14.

EFsA, 2004b. Opinion of the Scientific Panel on Dietetic Products, Nutrition and Allergies on a request from the Commission related to the presence of trans fatty acids in foods and the effect on human health of the consumption of trans fatty acids. EFSA J. 81, 1-49.

EFsA, 2008. Scientific opinion DHA and ARA and development of brain and eyes - Scientific substantiation of a health claim related to Docosahexaenoic Acid (DHA) and Arachidonic Acid (ARA) and support of the neural development of the brain and eyes pursuant to Article 14 of Regulation (EC). EFSA J. 794, 1-11.

EFSA, 2009. Scientific Opinion of the Panel on Contaminants in the Food Chain on a request from the European Commission on cadmium in food. EFSA J. 980, 1-139.

EFsA, 2010. Scientific Opinion on Dietary Reference Values for fats, including saturated fatty acids, polyunsaturated fatty acids, monounsaturated fatty acids, trans fatty acids, and cholesterol. EFSA J. 8, 1461.

EFSA, 2012a. Scientific Opinion on the risk for public health related to the presence of mercury and methylmercury in food. EFSA J. 10, $1-241$.

EFSA, 2012b. Scientific Opinion on the Tolerable Upper Intake Level of eicosapentaenoic acid
(EPA), docosahexaenoic acid (DHA) and docosapentaenoic acid (DPA). EFSA J. 10, 7, 2815.

EFSA, 2014. Scientific Opinion on the essential composition of infant and follow-on formulae. EFSA J. 12, 7, 3760.

EFSA, 2018. Scientific Opinion on the risk for animal and human health related to the presence of dioxins and dioxin-like PCBs in feed and food. EFSA J. 16, 11, 5333.

ESC/EAS, 2016. Guidelines for the management of dyslipidaemias: The task force for the management of dyslipidaemias of the European Society of Cardiology (ESC) and European Atherosclerosis Society (EAS). Atherosclerosis 253, 281-344.

FAO, 2010. Fats and fatty acids in human nutrition. Report of an expert consultation. Rome.

FAO, 2015. Consumption of fisheries and aquaculture products. https://ec.europa.eu/fisheries/6-consumption_en.

FAo/WHO, 1991. Protein quality evaluation. Report of the Joint FAO/WHO Expert Consultation. FAO Food and Nutrition Paper 51. Food and Agriculture Organization of the United Nations, Rome.

FAo/WHo, 2012. Public Health Risks of Histamine and other Biogenic Amines from Fish and Fishery Products.

FDA, 2017. Eating fish: What pregnant women and parents should know. https://www. fda.gov/food/resourcesforyou/consumers / ucm393070.htm

FSANZ, 2011. Mercury in fish. http://www.foodstandards.gov.au/consumer/chemicals / mercury/documents/mercury_in_fish_brochure_ lowres.pdf.

Galant K., BARG E., KazANOWSKA B., 2016. Witamina $D$ a choroby metaboliczne, autoimmunologiczne $i$ nowotworowe. Pediatr. Endocrinol. Diabetes Metab. 1, 31-37.

GAWIECKI J., WoźNIEWICZ M., 2010. Produkty spożywcze jako źródło składników odżywczych. [W:] Żywienie człowieka. Podstawy nauk o żywieniu. GAWECKI J. (red.). Wyd. PWN, Warszawa, 339-366.

Grosso G., Micek A., Marventano S., CastellaNO S., Mistretta A., PAJAK A., Galvano F., 2016. Dietary n-3 PUFA, fish consumption and depression: A systematic review and meta-analysis of observational studies. J. Affect. Disord. 205, 269-281.

He K., SONG Y., DaViglus M. L., LIU K., VAN HoRn L., DYer A. R., GoldBourT U., GREenLAND P., 2004. Fish consumption and incidence of stroke: a meta-analysis of cohort studies. Stroke 35, 1538-1542.

Heath J. C., Banna K. M., ReED M. N., PESeK E. F., Cole N., Li J., Newland M. C., 2010. Dietary selenium protects against selected signs of aging and methylmercury exposure. Neurotoxicology 31, 169-179.

HibBeln J. R., Ferguson T. A., Blasbalg T. L., 2006. Omega-3 fatty acid deficiencies in neurodevelopment, aggression and autonomic dysregulation: opportunities for intervention. Int. Rev. Psychiatry. 18, 107-118.

Hibbeln J. R., Davis J. M., Steer C., EmmetT P., Rogers I., Williams C., Golding J., 2007. Maternal seafood consumption in pregnancy and neurodevelopmental outcomes in childhood (ALSPAC study): an observational cohort study. Lancet 369, 578-585.

IERIGż-PIB, 2018. Rynek ryb stan $i$ perspektywy. IERiGZ̈-PIB, MIR-PIB, ARR, MRWiR, Warszawa, 29. 
JARosz M., 2016. Piramida zdrowego żywienia $i$ aktywności fizycznej dla osób dorosłych. Instytut Żywności i Żywienia, Warszawa, 1-9.

JAROSZ M., 2017a. Normy żywienia dla populacji Polski. Instytut Żywności i Żywienia, Warszawa.

JAROSZ M., 2017b. Piramida zdrowego żywienia $i$ aktywności fizycznej dla osób $w$ wieku starszym. Instytut Żywności i Żywienia, Warszawa, $1-12$.

JAROsZ M., 2019. Piramida zdrowego żywienia $i$ stylu życia dla dzieci $i$ młodzieży. Instytut Żywności i Żywienia, Warszawa, 1-12.

JEDRUSEK-GOLIŃSKA A., 2014. Alergie $i$ nietolerancje pokarmowe. [W:] Bezpieczeństwo żywności $i$ żywienia. GAWECKI J., KREJPCIO Z. (red.). Wyd. Uniwersytetu Przyrodniczego w Poznaniu, Poznań, 97-110.

JEZNACH-STEINHAGEN A., CZERWONOGRODZKA-SENCZYNA A., 2013. Postepowanie dietetyczne jako element leczenia zaburzeń płodności u mężczyzn $z$ obniżona jakościa nasienia. Endokrynol. Otyłość 9, 14-19.

Kantor E. D., Lampe J. W., Peters U., Vaughan T. L., WHITE E., 2014. Long-chain omega-3 polyunsaturated fatty acid intake and risk of colorectal cancer. Nutr. Cancer 66, 716-727.

KHAN F., ORSON F., OGAWA Y., PARKER C., DAVIS C. M., 2011. Adult seafood allergy in the Texas medical Center: A 13-year experience. Allergy Rhinol. 2, 71-77.

KoŁaKowsKa A., KoŁaKowsKi E., 2001. Szczególne właściwości żywieniowe ryb. Przem. Spoż. 6, 10-13.

KOT K., KOSIK-BOGACKA D., ŁANOCHA-ARENDARCZYK N., CIOSEK Ż., 2016. 'Wpływ zwiazków rteci na organizm człowieka. Farm. Współcz. 9, 210-216.

KREJPCIO Z., KRÓL E., 2014. Chemiczne $i$ fizyczne zanieczyszczenia żywności oraz substancje dodatkowe. [W:] Bezpieczeństwo żywności $i \dot{z} y$ wienia. GAWECKI J., KREJPCIO Z. (red.). Wyd. Uniwersytetu Przyrodniczego w Poznaniu, Poznań, 35-62.

KunACHOWICZ H., PRZYGODA B., NADOLNA I., IWANOW K., 2017. Tabele składu $i$ wartości odżywczej żywności. Wyd. Lekarskie PZWL, Warszawa.

LANDS B., 2016. Benefit-risk assessment of fish oil in preventing cardiovascular disease. Drug Saf. 39, 787-799.

LEŚNIEWSKA E., SZYNKOWSKA M. I., PARYJCZAK T., 2009. Główne źródła rteci $w$ organizmach ludzi nie narażonych zawodowo. Rocz. Ochr. Środ. 11, 403-419.

LOPATA A. L., O'HEHIR R. E., LEHRER S. B., 2010 Shellfish allergy. Clin. Exp. Allergy 40, 850858.

MAlesA-CiEĆWIERZ M., Usydus Z., 2015. Vitamin $D$ : can fish food-based solutions be used for reduction of vitamin $D$ deficiency in Poland? Nutrition 31, 187-192.

MANIA M., WOJCIECHOWSKA-MAZUREK M., STARSKA K., RebeniaK M., POSTUPOlsKi J., 2012. Ryby $i$ owoce morza jako źródło narażenia człowieka na metylortęć. Rocz. Panstw. Zakl. Hig. $63,257-264$

MARKHUS M. W., SKOTHEIM S., GRAFF I. E., FRøYLAND L., BRAARUD H. C., STORMARK K. M., MALDE M. K., 2013. Low omega-3 index in pregnancy is a possible biological risk factor for postpartum depression. PLoS One 8, e67617.

MARTYNOWICZ H., SKOCZYŃSKA A., 2004. Toksyczność kadmu. Kadm i nadciśnienie tętnicze. Pol. Arch. Med. Wew. 2, 243-248.
MOHAJERI M. H., TROESCH B., WeBer P., 2015. Inadequate supply of vitamins and DHA in the elderly: implications for brain aging and Alz heimer-type dementia. Nutrition 31, 261-275.

MoJska H., KŁosiewiCZ-LatoszeK L., JASIŃSKA-MELON E., GIELECIŃSKA I., 2017. Kwasy omega-3. [W:] Normy żywienia dla populacji Polski. JAROSZ M. (red.). Wyd. IŻŻ, Warszawa, 76-91.

NAFSTAD P., NystaD W., MAGNUS P., JAAKKOLA J. J., 2003. Asthma and allergic rhinitis at 4 years of age in relation to fish consumption in infancy. J. Asthma 40, 343-348.

Niewiadowska A., KiluaneK T., Semeniuk S., ŻMUDZKI J., 2012. Zawartość pestycydów chloroorganicznych i kongenerów polichlorowanych bifenyli w rybach battyckich. Med. Wet. 68, 114-118.

PALMER R. F., Blanchard S., WoOd R., 2009. Proximity to point sources of environmental mercury release as a predictor of autism prevalence. Health Place 15, 18-24.

PARKER G., HEGARTY B., GRANVILlE-SMith I., Ho J., PATERSON A., GOKIERT A., HADZI-PAVlOVIC D., 2015. Is essential fatty acid status in late pregnancy predictive of post-natal depression? Acta Psychiatr. Scand. 131, 148-156.

PAWliK D., LAUTERBACH R., WALCZAK M., HuRKala J., 2011. Docosahexaenoic acid (DHA) concentration in very low birth weight newborns receiving a fish-oil based fat emulsion from the first day of life. Preliminary clinical observation. Med. Wieku Rozw. 15, 312-317.

PietrZAK-FieĆKO R., PAROL J., KUBIAK M.S., 2015. Porównanie zawartości wielopierścieniowych weglowodorów aromatycznych (WWA) $w$ wedzonych tradycyjnie rybach słodkowodnych. Nauka Przyr. Technol. 9, 3, 1-9.

PIWET-PIB, 2018. Raport $z$ badan kontrolnych dioksyn, furanów, dioksypodobnych polichlorowanych bifenyli (dl-PCB) i niedioksypodobnych $P C B$ (ndl-PCB) u zwierzat $i w$ produktach pochodzenia zwierzecego przeprowadzonych $w$ 2017r. Państwowy Instytut Weterynaryjny Państwowy Instytut Badawczy Zakład Radiobiologii, Puławy, 1-24.

POLAK-JUSZCZAK L., 2008. Zawartość składników mineralnych $w$ rybach wedzonych. Rocz. Państ. Zakł. Hig. 59, 187-196.

POLAK-JUSZCZAK L., ADAMCZYK M., 2009. Jakość $i$ skład aminokwasowy biatka ryb z zalewu Wiślanego. Żywn. Nauka Technol. Jakość, 3, 75-83.

POLAK-JUSZCZAK L., UsYdUS Z., 2006. Makro i mikroelementy $w$ konserwach ze szprotów. Rocz. Państ. Zakł. Hig. 57, 347-354.

RASFF, 2018. The Rapid Alert System for Food and Feed Annual Report 2017. European Union, Luxembourg, 1-58.

REES A., SiROIS S., WEARDEN A., 2014. Maternal docosahexaenoic acid intake levels during pregnancy and infant performance on a novel object search task at 22 months. Child Dev. 85, 2131-2139.

RogaCKA M., WASZCZUK-JANKOWSKA M., CIESIELSKI T., Szefer P., 2003. Owoce morza jako źródło mikro i makroelementów. Bromat. Chem. Toksykol. 36 (Suppl.), 55-60.

RosiŃSKA A., DABROWSKA L., 2011. PCB i metale ciéżkie $w$ wodzie $i$ osadach dennych zbiornika Kozłowa Góra. Arch. Environ. Prot. 37, 6173.

ROZPORZADZENIE 1881, 2006. Rozporzadzenie Komisji (WE) $n r$ 1881/2006 $z$ dnia 19 grudnia 2006 r. ustalajace najwyższe dopuszczalne poziomy niektórych zanieczyszczen $w$ środkach spożywczych. Dz. U. UE nr L364/5 z 
dnia 20.12.2006 z późn. zm. https://eur-lex. europa.eu/legal-content/PL/TXT/?uri=cele$\mathrm{x}: 32006 \mathrm{R} 1881$

ROZPORZADZZNIE 835, 2011. Rozporzadzenie Komisji (UE) $n r$ 835/2011 z dnia 19 sierpnia 2011 r. zmieniajace rozporzadzenie (WE) $n r$ 1881/2006 odnośnie do najwyższych dopuszczalnych poziomów wielopierścieniowych weglowodorów aromatycznych $w$ środkach spożywczych. https://eur-lex.europa.eu/legal-content/PL/ALL/?uri=CELEX:32011R0835.

ROZPORZADZENIE 1259, 2011. Rozporzadzenie Komisji (UE) $n r$ 1259/2011 z dnia 2 grudnia 2011 r. zmieniajace rozporzadzenie (WE) $n r$ $1881 / 2006 w$ odniesieniu do najwyższych dopuszczalnych poziomów dioksyn, polichlorowanych bifenyli o działaniu podobnym do dioksyn $i$ polichlorowanych bifenyli o działaniu niepodobnym do dioksyn $w$ środkach spożywczych. Dz. U. UE nrL 320 z dnia 3.12.2011 z późn. zm. https://eur-lex.europa.eu/legal-content/PL/TXT/?uri=CELEX:32011R1259

RUSIŃSKA A., PŁUDOWSKI P., WALCZAK M., BORSZEWSKA-KoRNACKA M., BossowsKI A., CHLEBNA-SOKÓE D., CZECH-KowALSKA J., DOBRZAŃSKA A. i współaut., 2018. Zasady suplementacji $i$ leczenia witamina $D$ - nowelizacja 2018 r. Post. Neonatol. 1, 1-24.

SteEnWEG-DE GRAAFF J. C., Tiemeier H., BASTEN M. G., RIJLAARSDAM J., DEMMELMAIR
H., Koletzko B., Hofman A., Jaddoe V. W., VERHULST F. C., ROZA S.J., 2015. Maternal LC-PUFA status during pregnancy and child problem behavior: the Generation $R$ Study. Pediatr. Res. 77, 489-497.

SuPREWICZ K., KozIKOWSKA I., 2014. Stężenie rteci $w$ łożysku $i$ błonie płodowej kobiet oraz we krwi pepowinowej a masa urodzeniowa noworodków. Episteme 22, 271-279.

WAWRZYNIAK A., MINCER-CHOJNACKA I., KALICKI B., LIPIŃSKA-OPAEKA A., JOBS K., STELMASIAK A., 2015. Plejotropowe działanie witamin $D i K$. Pediatr. Med. Rodz. 4, 374-381.

WEKER H., DYLAG H., BARAŃSKA M., 2014. Schemat żywienia dzieci $w$ pierwszym roku życia Żywienie niemowlat $i$ małych dzieci. [W:] Zasady postępowania $w$ żywieniu zbiorowym. WEKER H., BARAŃSKA M. (red.). Instytut Matki i Dziecka, Warszawa, 17-28.

WOJCIECHOWSKA-MAZUREK M., MANIA M., STARSKA K., OPOKA M., 2010. Kadm w środkach spożywczych - celowość obniżenia limitów. Przem. Spoż. 64, 45-48.

YuRKo-MAuRO K., ALEXANDER D. D., VAN ElSWYK M. E., 2015. Docosahexaenoic acid and adult memory: A systematic review and meta-analysis. PLoS One 10, e0120391.

KOSMOS Vol. 68, 2, 269-281, 2019

\section{Olga JanuszKo, JoANna KaŁUŻa}

Department of Human Nutrition,_Faculty of Human Nutrition and Consumer Sciences, Warsaw University of Life Sciences - SGGW, 159C Nowoursynowska Str., 02-766 Warszawa,E-mail: olga_januszko@sggw.pl

FISH AND FISH PRODUCTS IN HUMAN NUTRITION - ANALYSIS OF BENEFITS AND RISKS

\section{Summary}

Fish and seafood are important elements of a properly balanced diet at every stage of human development and life. Generally, consuming of fish at least twice a week is recommended by nutritionists in the world to prevent ischemic heart disease and cancer. However, due to the risk of contamination of these products by such compounds as methylmercury and dioxin, for vulnerable groups (pregnant women, breastfeeding mothers and children), some restrictions on their consumption were introduced. At the same time, it is emphasized that the health benefits of moderate fish consumption by pregnant women outweigh the risks. In many countries, educational activities have been undertaken regarding nutritional recommendations to limit the intake of certain marine fish species due to a high level of contamination by methylmercury. Education regarding fish consumption, their nutritional value and selection of appropriate species of pregnant women, breastfeeding and in childbearing age women seems to be very important.

Key words: consumption, dioxins, long chain polyunsaturated fatty acids, fish, methylmercury, nutritional value, seafood, vitamin D 